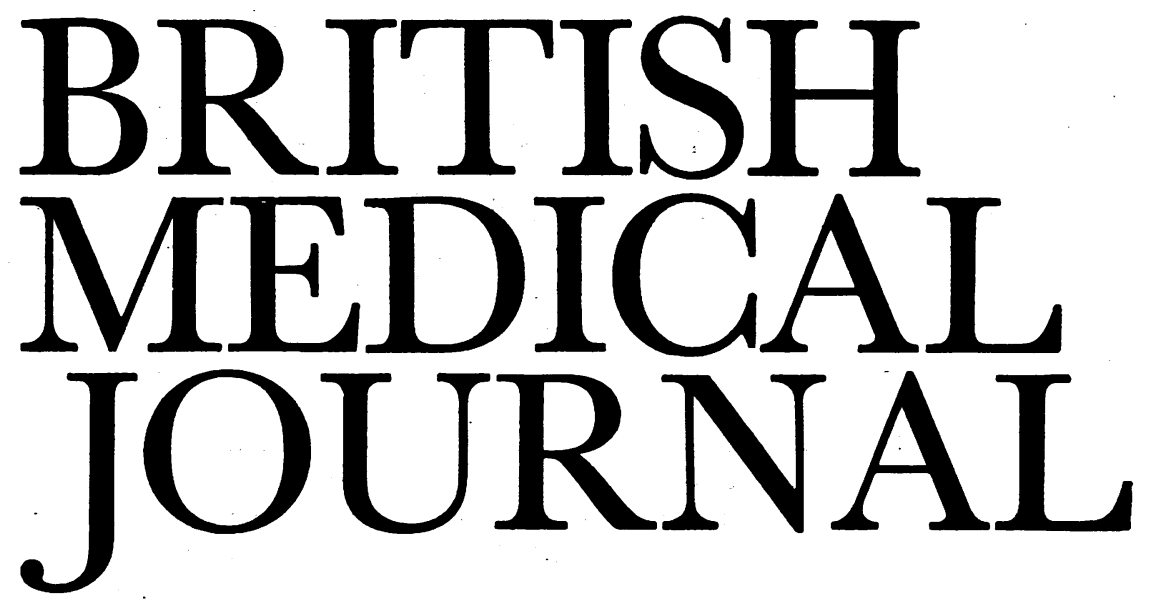

LONDON, SATURDAY 3 JANUARY 1987

\title{
Unanswered questions on neural tube defects
}

Although much is known about neural tube defects, several important questions are unanswered. For instance, what is the cause of the defects and why are they becoming less common in most parts of the world?

Anencephaly, spina bifida, and encephalocele may result from single mutant genes, chromosome abnormalities, or direct intrauterine influences, or by the combined action of unknown genetic and environmental factors. This last multifactorial group make up $90 \%$ of those affected at birth. ${ }^{1}$

The birth prevalence of neural tube defects shows a wide geographical variation, both between and within countries. They are, for instance, commoner in Europe than Asia or Africa and within Britain they are commoner in Northern Ireland than in south east England. ${ }^{2}$ Furthermore, the prevalence in any one place oscillates over time: there are cyclical peaks and troughs that are not necessarily paralleled in different areas. ${ }^{3}$ What is remarkable is that the decline that began in Britain in $1972^{4}$ is showing no sign of reversing. Today we thus have the lowest prevalence recorded. In 1972 the prevalence of central nervous system malformations in England and Wales was $4 \cdot 26 / 1000$ births $^{4}$; in 1984 (the latest available figures) it was $1 \cdot 26 / 1000 .^{5}$ This decrease has not been seen with other malformations and seems worldwide. It has been seen in the Netherlands, ${ }^{6}$ where it began in 1955, Scandinavia and Canada, ${ }^{7}$ Hungary, ${ }^{8}$ and Australia. ${ }^{9}$

The prevalence of a congenital malformation at birth is sometimes far less than the true incidence-that is, the number formed at or shortly after conception. The rate of neural tube defects in fetuses spontaneously aborted is roughly ten times that at birth..$^{10-12}$ In 1973 Roberts and Lloyd proposed that geographic differences in prevalence arose not because of varying incidence rates, but because of differences in the number of fetuses with neural tube defects that were aborted..$^{13}$ MacHenry et al,$^{12}$ however, found no significant difference in the number of fetuses with neural tube defects that miscarried between Northern Ireland (an area with a high birth prevalence) and London ${ }^{10}$ (an area of lower prevalence). In a recent paper Byrne and Warburton ${ }^{14}$ have compared the relative rates of neural tube defects in spontaneously aborted fetuses and in those born at term in four areas with different birth prevalences-New York, London, ${ }^{10}$ Edinburgh, ${ }^{11}$ and Belfast. ${ }^{12}$ They discovered a strong positive association between the pairs of rates, which suggests strongly that the true incidence is different between geographical areas. In addition, they karyotyped the abortuses and made comparisons with the London study. The overall rate of neural tube defects in embryos was significantly lower in New York than in London, but the rate of chromosomally abnormal individuals with neural tube defects was similar: the difference in the overall rate was thus almost entirely due to individuals with a normal karyotype. This suggests that the incidence of neural tube defects associated with chromosome abnormalities may be uniform and that it is the incidence of defects with normal chromosomes (predominantly the multifactorial type) that varies geographically.

The geographically and temporally varying incidences in multifactorial neural tube defects are, however, not explained, and the cause is still unknown: genetic factors must zontribute; neural tube defects are more common in females than in males; they recur in siblings; and there is ethnic variation. In India neural tube defects are commoner in Sikhs than in other groups, ${ }^{15}$ and in the British Isles they are commoner in Celts than in other Europids. ${ }^{16}$ The secular variations and the current downward trend in prevalence imply environmental influences as well, particularly as the decline is greatest in areas with high prevalences.

In the past 10 years prenatal diagnosis and abortion of affected fetuses have played an increasingly large part in reducing births of babies with neural tube defects-so influencing the prevalence but not the incidence. When prenatal diagnosis was restricted to high risk cases, it had little effect on overall births with neural tube defects, but as whole populations have been screened by measuring maternal serum $\alpha$ fetoprotein concentration and, more recently, by high resolution ultrasound scanning the impact has been appreciable. ${ }^{17}{ }^{18}$ Prenatal diagnosis is not, however, the sole explanation for the decline in prevalence-it does not account for the entire deficit in numbers. ${ }^{4}{ }^{19}$ Also, the decrease began in most places before prenatal diagnosis was available, and it has been seen in the Republic of Ireland, ${ }^{20}$ where there are no screening programmes and no terminations of pregnancy.

Other possible explanations for the fall have been explored and eliminated. The overall birthrate has dropped, but there has been no decrease in the rate of other congenital malformations. Births have not declined disproportionately among 
women at high risk - very young and older women, and those from social classes IV and V. ${ }^{4}{ }^{21}$ Neural tube defects might have been prevented by periconceptional vitamin supplementation, ${ }^{22}$ increasing awareness of the importance of diet both before and during pregnancy, and the wider availability of nutritious foodstuffs. But this is not consistent with observations in Sheffield ${ }^{18}$ and Paisley ${ }^{23}$ that the dramatic decline has occurred concurrently with massive local unemployment and a deteriorating social climate.

So the cause of neural tube defects and their decline remains tantalisingly elusive: we have a plethora of data but no explanation.

Reader in Developmental Genetics,

MARY J SELLER

Paediatric Research Unit,

United Medical and Dental Schools of

Guy's and St Thomas's Hospitals,

London SE1 9RT

1 Holmes LB, Driscoll SG, Atkins L. Etiologic heterogeneity of neural-tube defects. N Engl f Med 1976;294:365-9.

2 Leck I. Causation of neural tube defects: clues from epidemiology. Br Med Bull 1974;30:158-63. 3 Elwood JM, Elwood JH. Epidemiology of anencephalus and spina bifida. Oxford: Oxford University Press, 1980.

4 Bradshaw J, Weale J, Weatherall J. Congenital malformations of the central neroous system. London: HMSO, 1980:13-8. (Population Trends, No 19.)

5 Office of Population Censuses and Surveys. Congenital malformations 1984. OPCS Monitor, MB3 85/2. London: HMSO, 1985.

6 Romijn JA, Treffers PE. Anencephaly in the Netherlands: A remarkable decline. Lancet 1983;i:64-5.

7 International Clearinghouse for Birth Defects monitoring systems. Annua! report. San Francisco: International Clearinghouse, 1981 .

8 Czeizel A. Spina bifida and anencephaly. Br Med $\mathcal{3} 1983 ; 287: 429$.

9 Danks DM, Halliday JL. Incidence of neural tube defects in Victoria, Australia. Lancet 1983;i:65.

10 Creasy MR, Alberman ED. Congenital malformations of the central nervous system in spontaneous abortions. $\mathcal{F}$ Med Genet 1976;13:9-16.

11 Bell JE, Gosden CM. Central nervous system abnormalities-contrasting patterns in early and late pregnancy. Clin Genet 1978;13:387-96.

12 MacHenry JCRM, Nevin NC, Merrett JD. Comparison of central nervous system malformations in spontaneous abortions in Northern Ireland and south-east England Br Med f 1979;i:1395-7.

13 Roberts CJ, Lloyd S. Area differences in spontaneous abortion rates in South Wales and their relation to neural tube defect incidence. BrMed f 1973;iv:20-2.

relation to neural tube defect incidence. Br Med $\mathcal{F} 1973$;iv:20-2.
Byrne J, Warburton D. Neural tube defects in spontaneous abortions. Am f Med Genet, in press.

14 Byrne J, Warburton D. Neural tube defects in spontaneous abortions. Am f Med Genet,

16 Carter CO; Evans K. Spina bifida and anencephalus in Greater London. F Med Genet 1973;10: Carter CO

17 Ferguson-Smith MA. Spina bifida and anencephaly. Br Med f 1983;287:428-9.

18 Lorber J, Ward AM. Spina bifida-a vanishing nightmare? Arch Dis Child 1986;60: 1086-81.

19 Carstairs V, Cole S. Spina bifida and anencephaly in Scotland. Br Med $\mathcal{J} 1984 ; 289: 1182-4$.

20 Kirke PN, Elwood JH. Anencephaiy in the United Kingdom and Republic of Ireland. Br Med J 1984;289:1621.

21 Owens JR, Harris F, McAllister E, West L. 19-year incidence of neural tube defects in area under constant surveillance. Lancet 1981; ii:1032-5.

22 Smithells RW, Sheppard S, Schorah CJ, et al. Apparent prevention of neural tube defects by periconceptional vitamin supplementation. Arch Dis Child 1981;56:911-8.

23 Shepherd RC. Spina bifida and anencephaly. Br Med f 1983;287:59.

\section{Medicine and managers}

Better Management, Better Health, the new report from the National Health Service Training Authority, deserves the attention of doctors not just because it offers to improve health but also because it seeks to involve all professions in management. ${ }^{1}$ Furthermore, the training authority wants responses from those working in the National Health Service.

The report is aimed at the health departments of England and Wales, the NHS, and the training authority itself and is based on the conclusions of several working groups made up of educators and managers. It begins with the premise that all elements of the service should be actively managed and that "tribal" groups should not be left to regulate their own affairs. Doctors are encouraged to initiate proposals to improve performance rather than merely respond to the ideas and directives of management.
Changes are recommended not only from the haphazard or non-existent assessment of staff but also from the inflexible $\underline{\underline{T}}$ and didactic traditional methods of management education. 3 Managers must know more about the "core technology" of $\stackrel{\unrhd}{\complement}$ the service, and doctors should learn effective management $\check{c}$ and apply it to their own work. To this end the training authority seeks to work with interested professional bodies (it does so with the BMA) and to publish general recom- $\mathbb{D}$ mendations on management development for doctors.

Inevitably this will cost time, energy, and money, and the report recommends that $0.5 \%$ of payroll expenditure should $\underset{\vec{F}}{\vec{P}}$ be on management development. Currently, despite being $\overrightarrow{0}$ the largest employer in Britain, the NHS has no quantifiable $\overline{0}$ national budget for this-nor is any new money suggested. $\frac{\bar{m}}{7}$

This brave manifesto is presented in refreshing style with $\stackrel{\mathbb{\Omega}}{\Omega}$ colourful cameos of staff (looking industrious and happy) and, of course, patients. The assumption implicit in the $\vec{\circ}$ title-that better management will lead to better healthis appealing but not proved. Yet investment will have $\overrightarrow{\vec{\omega}}$ to compete with other "good things" such as health pro- $\frac{\rho}{O}$ motion - not to mention patient services. None the less, the 3 need to use resources effectively cannot be denied-and the principles proposed by the training authority deserve general support.

The report is directed mainly at the development of full time managers but acknowledges the role of others. Its $\vec{\circ}$ implications for doctors will become clearer when more $\omega$ specific proposals are presented by the training authority. These will no doubt be based on the response to the authority's recently published discussion document Developing the Role of Doctors in the Management of the NHS. ${ }^{2}$

The authority must recognise that doctors manage staff and commit resources as well as provide services. Their management contribution ranges from clinical practice through functional management of clinical departments to working in the medical advisory structure or even being a general manager. At all levels there is a common need to practise principles of planning, organisation, direction, and $\stackrel{2}{\vec{F}}$ control. The message from the training authority should not $\frac{9}{3}$ therefore be alien to doctors, but it does imply further questions about undergraduate and postgraduate training and about how doctors organise themselves locally.

Firstly, at what stage in a doctor's career should management development begin? Better Management, Better Health $\dot{5}$ focused on the established practitioner, and many courses are already available-especially to senior registrars, junior $\frac{\rho}{8}$ consultants, and new principals in general practice. In some regions participation in an approved management course is already a condition of consultant appointment, but should $\mathrm{N}$ the principles not be introduced to all medical students? $\frac{D}{O}$

Secondly, much "management" is already inherent in good clinical practice; doctors should define the purpose of $\tilde{N}$ investigation and treatment, choose the best options, and $\tilde{\omega}$ review quality and effectiveness. So it would be logical to develop links between clinical and management education $\stackrel{0}{\circ}$ and to hope for the active cooperation of the royal colleges, $\stackrel{\mathbb{D}}{\rightarrow}$ the professional bodies, and those responsible for postgraduate training.

Thirdly, the current management revolution begs a reappraisal of the medical advisory structure. If doctors are to $\frac{\mathbb{\Phi}}{\mathbb{Q}}$ have a say in management they must have their own $\bar{\sigma}$ corporate, responsive, and effective local mechanisms. Now $\delta$ is a good time to re-examine and overhaul the cogwheel machinery (now rusting in parts) so it will meet the challenge to provide advice to health authorities and to maintain a negotiated independence. 